\title{
Distinções primordiais entre Canto e Fala a partir de
}

\section{Aristóxeno de Tarento}

\author{
Paulo Eduardo de Barros Veiga, Rubens Russomanno Ricciardi \\ Universidade de São Paulo | Brasil
}

\begin{abstract}
Resumo: Com base nos tratados musicais de Aristóxeno de Tarento (século IV a. C.), o músico primordial, procura-se compreender como se operacionaliza semanticamente a distinção entre canto e fala, após uma revisão inevitável sobre ritmo, métrica e prosódia. Sobre esses conceitos, procura-se propor uma triagem epistemológica, considerando a música, a poesia e a dança. Do contrário, suscitam-se equívocos semânticos cuja consequência mais nociva seja o

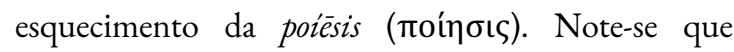
Aristóxeno estabelece uma teoria inteiramente preocupada com a episteme musical. Essas discussões de teor filosófico-epistemológico desdobram-se a partir do escopo central, qual seja, a diferença entre canto e fala. O ensejo permite comentar também sobre a distinção entre vogais longas e breves na concepção tanto da prosódia das línguas antigas, com destaque ao latim, quanto da prosódia musical, com extensão às línguas modernas, contribuindo, dessa forma, com o ofício do compositor.
\end{abstract}

Palavras-chave: Epistemologia, Teoria musical grega, Prosódia, Canto e Fala, Aristóxeno de Tarento.

\begin{abstract}
Based on the musical treatises of Aristoxenus of Tarentum (4th century BC), the primordial musician, one seeks to understand, in a semantic approach, the distinction between singing and speaking, after an inevitable revision on rhythm, metrics, and prosody. In this point of view, one proposes an epistemological triage of concepts in common with music, poetry, and dance. Otherwise, semantic misunderstandings can obliviate the poiesis

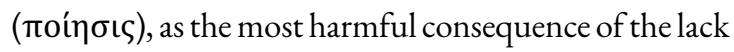
of conceptual distinction. One adds that Aristoxenus establishes a theory entirely concerned with musical episteme. Moreover, it is an occasion to discuss some philosophical-epistemological issues regarding the difference between long and short vowels as a prosodic phenomenon of the ancient languages, highlighting the Latin, including musical prosody, with extension to modern languages. These thoughts seem to contribute to the activity of composing.
\end{abstract}

Keywords: Epistemology, Greek musical theory, Prosody, Song and Speech, Aristoxenus of Tarentum. 
Aristoxenus, musicus idemque philosophus

Aristóxeno, músico e também filósofo ${ }^{1}$

(Cícero, Tusc., I, 19.13-14).

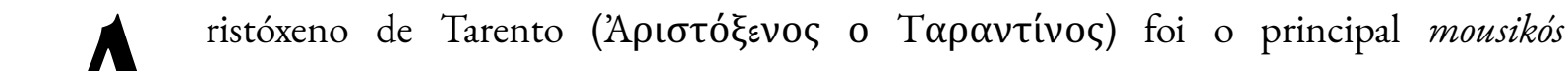

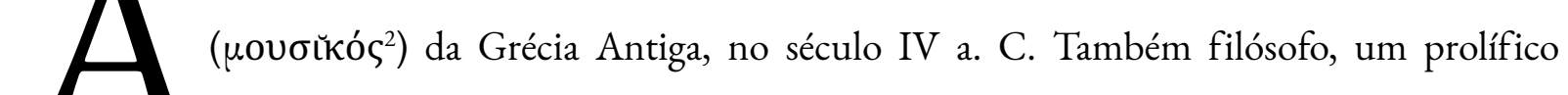 2 historiador e um dos principais discípulos de Aristóteles de Estagira (384-322 a. C),} organizou o conhecimento musical e cunhou importantes conceitos, como sýstēma téleion ( $\sigma u ́ \sigma \tau \eta \mu \alpha$

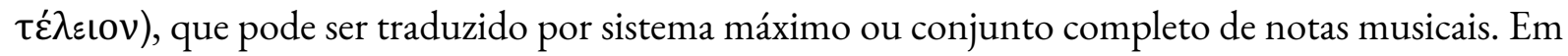
função da importância de seus textos, principalmente dos tratados de harmonia e de ritmo, tornouse a mais fundamental referência de pensador da Música. ${ }^{3}$

Embora tenha escrito muito sobre História, Filosofia e Educação, são os seus dois tratados

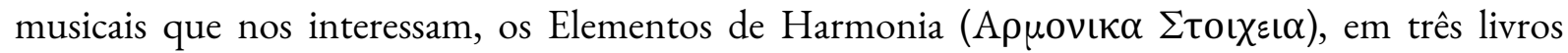

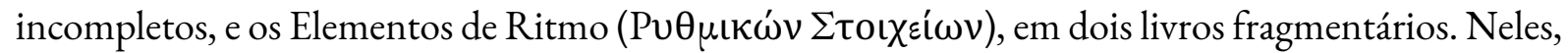
o filósofo organiza a teoria musical como nunca feito antes, muitas vezes refutando ou aprimorando o pensamento de seus antecessores, com destaque a Laso de Hermíone $e^{4}$ Epígono de Ambracia, Pitágoras e, principalmente, Aristóteles, o seu mestre.

Embora houvesse, anteriores a Aristóxeno, outros pensadores da música - muitos nomes irrecuperáveis -, todo o estabelecimento conceitual mais importante na área foi feito pelo tarentino (nascido na antiga cidade do Sul da Itália), quem, de fato, fundamentou a tradição teórico-musicals, sendo, portanto, o grande inventor da teoria musical. Seus principais epígonos, na Grécia Antiga, foram Aristides Quintiliano, Cleônides e Ptolomeu, que influenciaram muitos pensadores

\footnotetext{
1 Todas as traduções são nossas, exceto quando apontado o nome do tradutor.

2 O termo grego expressa com mais precisão a noção do que é vir a ser um músico na concepção filosófica, diferentemente do termo em português, que pode remeter somente ao cantor ou instrumentista.

3 Dedica-se este artigo a Lucas Eduardo da Silva Galon.

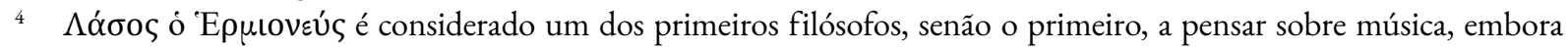
ainda de modo incipiente.

5 Importante lembrar que, praticamente, não temos acesso à arte musical grega, como poética, senão à teoria, como

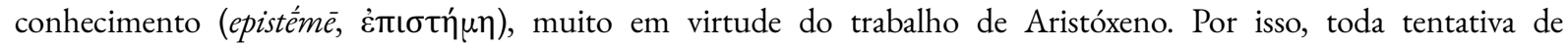
reconstrução artística da música grega antiga é sempre uma improbabilidade a que se deve todo resguardo.
} 
posteriores, com destaque aos teóricos da Idade Média e do Renascimento que se expressaram em língua latina. Assim, fundamentos de Aristóxeno também podem ser encontrados quer em Martianus Capella ${ }^{6}$, no século V d. C., perpassando por Cassiodorus, Boethius, Franchinus Gaffurius, Henricus Glareanus, quer em Franciscus Blanchinus Veronensis, já no século XVII, dentre outros teóricos cujos fundamentos advenham diretamente do músico da Magna Grécia.

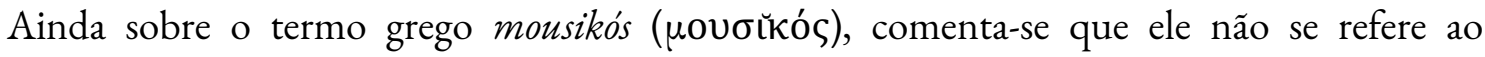

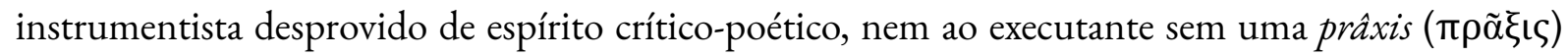
inventiva-reflexiva. De fato, o instrumentista precisa demonstrar outras faculdades para tornar-se um

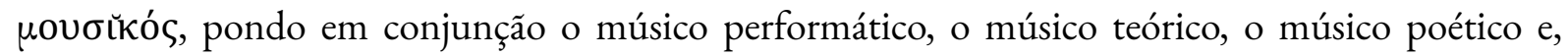

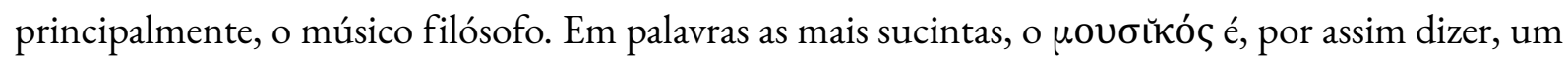
filósofo da harmonia, dotado de crítica, de percepção e de conhecimento. Nesse viés, o músico é, antes de tudo, aquele que pensa sobre música com parâmetros crítico-filosóficos. Logo, músico é quem

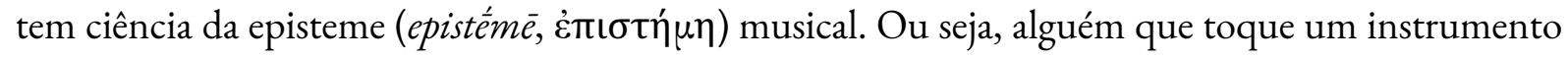
ou cante não é necessariamente um músico.

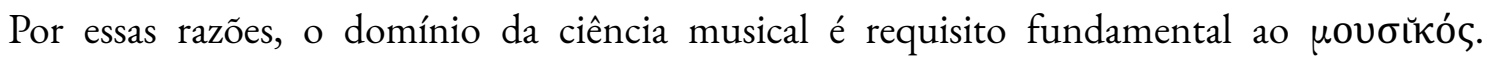
Outrossim, Aristóxeno ressalta a importância de o aprendiz de música ser dotado de um ouvido exato

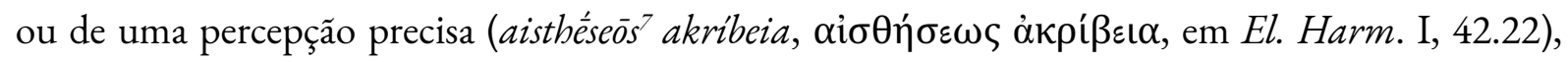

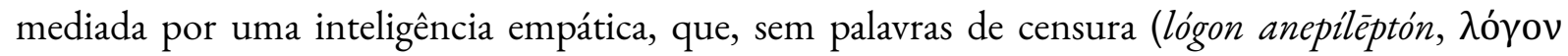
$\grave{\alpha} v \varepsilon \pi i ́ \lambda \eta \pi \tau o ́ v$, em El. Harm., I, 21.14), dispõe-se a ouvir. Com essa última expressão, entende-se que o estudante de música não deve censurar ou criticar seus mestres, senão desejar aprender com eles. Notadamente, Aristóxeno ensina-nos uma lição de humildade, postura essencial de um músico diante do ilimitado aprendizado musical. Essa postura empática quiçá tivesse impedido Hércules, ao ser repreendido, de ter matado o seu professor de lira, Lino, na famosa história grega ${ }^{8}$.

\footnotetext{
${ }^{6}$ Prioriza-se a versão latina de seus nomes, pelo correspondente imediato à língua de produção.

${ }^{7}$ Se retiradas de um contexto frasal específico, algumas palavras ou expressões em grego antigo permanecem em sua forma original, sem que se apresentem, necessariamente, no nominativo singular.

${ }^{8}$ Há inúmeras fontes que relatam essa história. Pode-se mencionar, por exemplo, Nicômaco de Gerasa (século I d. C.),

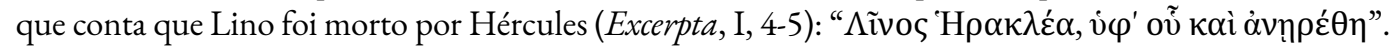


FIGURA 1 - Vaso ático de figuras vermelhas retratando o conflito entre o jovem Hércules e seu professor de lira, Lino.

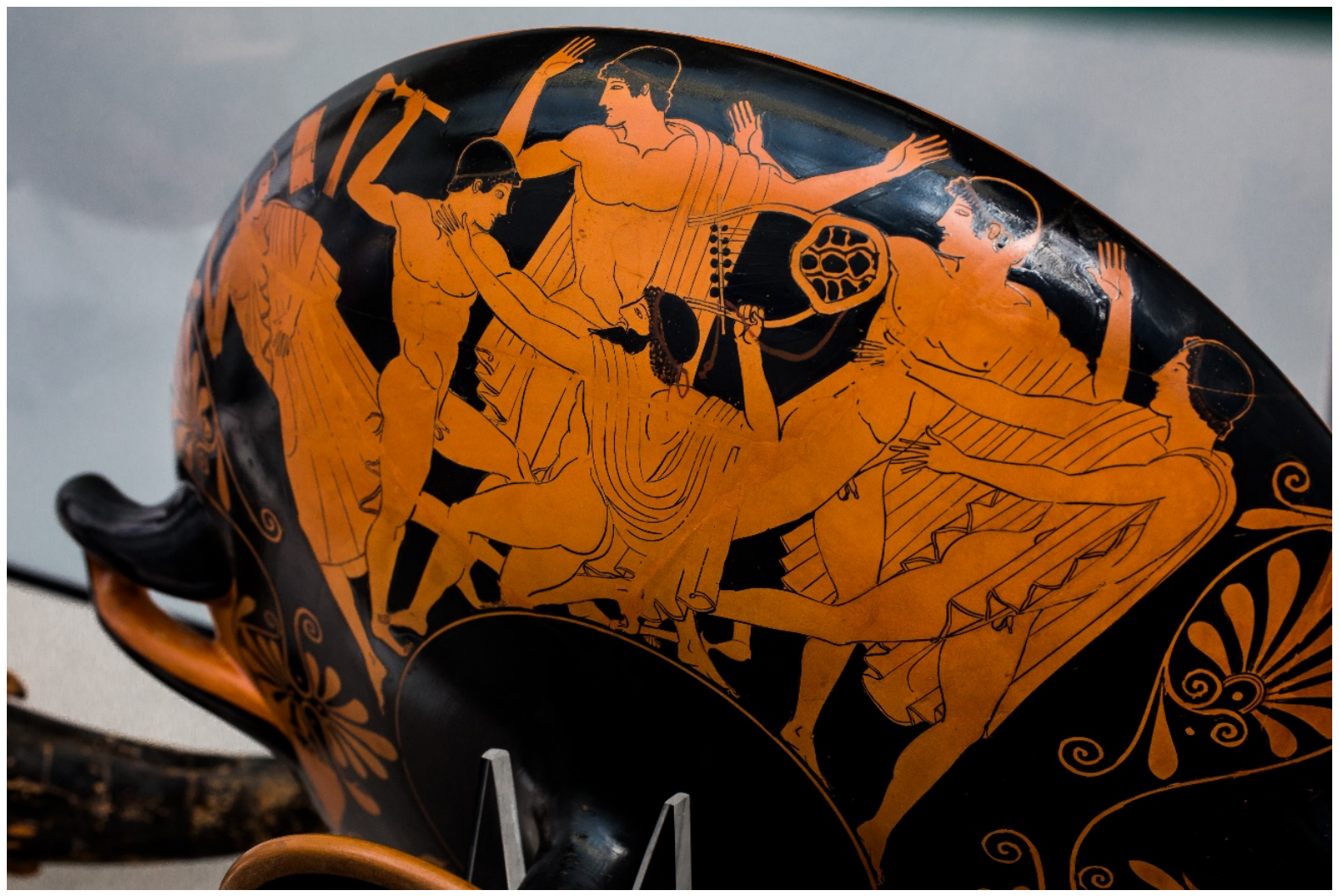

Fonte: Staatliche Antikensammlungen, München. (Vaso número 2646). Atribuído a Duris ( $\Delta$ oúpıs, Doûris), pintor e ceramista ateniense (século V a. C.). Foto da galeria de ArchaiOptix (2015).

Portanto, é imprescindível a quem quer ser músico dominar a episteme musical, além de ter bom ouvido e inteligência empática. Outrossim, o músico necessita ter "o conhecimento daqueles assuntos [da Harmonia] a serem assimilados, por meio dos quais se observa tudo aquilo relativo à música. Esta é, pois, a condição do músico” (Aristóxeno, El. Harm. I, 1, 13-15)9. Em síntese, músico é aquele de pleno conhecimento intelectual e sensorial sobre todos os assuntos relacionados à música, com destaque à Harmonia e ao Ritmo.

Em seus tratados, percebe-se a preocupação de Aristóxeno em sistematizar, com rigor teórico, a epistemologia musical, incluindo uma divisão precisa da ciência da harmonia. Por exemplo, embora

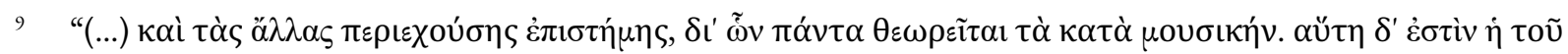

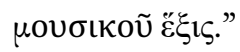




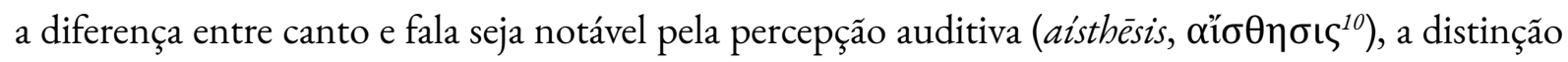
de conceitos ainda é muito tênue entre poesia e música, incluindo outros campos artísticos como a dança, haja vista, por exemplo, termos como rhythmós $\left(\dot{\rho} \cup \theta \mu o^{11}\right)$ e prosōidia $\left(\pi \rho 0 \sigma \omega \delta^{\prime} \alpha^{12}\right)^{13}$. Por essa razão, Aristóxeno procura entender cada conceito estritamente em contexto musical, não obstante o compartilhamento semântico com outras áreas. Afinal, essas noções podem servir a um número amplo de fenômenos artísticos, como se percebe tanto na composição musical quanto poética. Ademais, nessa partilha, apesar de cada conceito ter sido bem estabelecido em cada área, já a distinção entre as disciplinas pode não ser tão clara assim (GIBSON, 2005, p. 82).

Dessa forma, Aristóxeno toma algum tempo procurando definir qual seja a sua área de estudo e as tarefas que devem ser realizadas para compreender determinado domínio, o que expressa uma organização rigorosa. Outrossim, preocupado com a clareza epistemológica, o músico de Tarento inicia o seu "Elementos de Ritmo" delimitando a área de estudo, ainda mais em relação a uma noção tão ampla, como é o rhytmós ( $\dot{\rho} \theta \mu$ ós).

De fato, são muitas as naturezas do ritmo. Foi discutido anteriormente sobre o tipo de cada uma delas e o motivo pelo qual cada uma aconteceu de ser denominada da mesma forma e também o que cada uma implica. Mas agora cabe a mim falar sobre a disposição do ritmo especificamente na música ${ }^{14}$ (El. Rhythm. II, 17.1-5).

Em outras palavras, o músico limita a episteme geral ao campo da música, ainda mais em se tratando de conceitos que operam de modo semelhante. Em função disso, ele identifica a relação de sentido de um conceito entre os campos da arte e delimita o valor semântico a uma área específica. Essa triagem conceitual, em síntese, é um dos princípios de sua metodologia. Por consequência, a metodologia de Aristóxeno consegue solucionar o problema do espelhamento conceitual nas artes.

10 Estesia. Em nossa metodologia, restringimos o termo estesia e suas variantes (estésico, estético) somente àquilo que é mediado pelos sentidos de quem vê ou ouve, no sentido de percepção da obra. Logo, diferenciamos estético e poético, a despeito dos tratados de estética a partir de Baumgarten (1983, [1750/58]).

11 Ritmo. El. Harm. II, 41.10 e El. Rhythm., passim.

12 Prosódia. El. Harm. I, 23.14.

13 Por isso, é mister distinguir o ritmo da poesia e o fenômeno rítmico musical; do mesmo modo, a prosódia entre as línguas, quer antigas quer modernas, e a prosódia da música, considerando o estabelecimento de homologias entre texto e música.

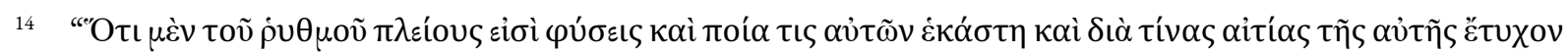

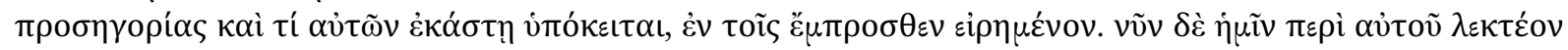

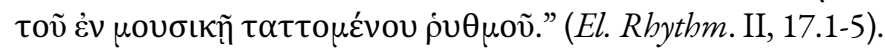


A preocupação de Aristóxeno em estabelecer a semântica de termos fundamentais é uma constante em seus tratados. De fato, ele isola questóes de que não tratará, excluindo de seu escopo assuntos perpendiculares ao tema. Por exemplo, o filósofo aponta dificuldades em sistematizar a dança devido à sua complexidade de categorização, maior que na música, muito devido ao suporte ou à 'constituiçãa esquemática' (gestos e passos, ao invés de notas ou de palavras). Por isso, ele distingue

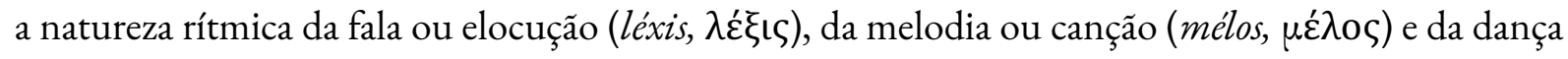

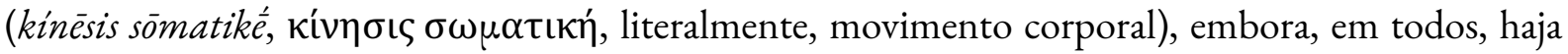

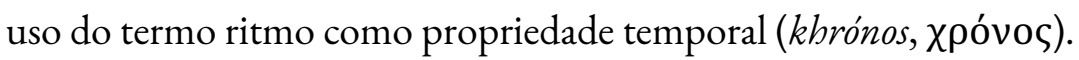

O tempo divide-se por medidas ritmadas em cada uma de suas partes. Essas medidas de tempo são três: a fala, o canto e a dança. Sendo o tempo divisível, então a fala dividir-se-á conforme as suas partes, tais quais letras, sílabas e palavras; o canto, em notas, tanto em intervalos quanto em escalas; a dança, sob esquemas, isto é, fração de movimento (Aristóxeno, El. Rhythm. II, 19.14-20). ${ }^{15}$

Há, dessa forma, uma distinção da natureza de sistemas, que não comportam as mesmas propriedades, porque não possuem os mesmos elementos. No entanto, embora cada sistema seja absolutamente distinto de outros, podem se servir de mesmas terminologias, porque tanto a música quanto a dança, por exemplo, possuem o tempo como elemento geral e primevo (assistemático). Eles se tornam ritmo, passos ou métrica (e não tempo) a partir de suas funções, já organizados os elementos sob sistema. Haja vista que o sistema poético, por exemplo, seja diferente do musical, figuras rítmicas e pés métricos possuem funcionalidades absolutamente distintas.

Também, Aristóxeno importa-se menos com as configurações éticas da música, diferentemente de Platão, assim como com as relações numéricas, como queriam os pitagóricos. Conforme Massimo Raffa (2020, p. 318): "Aristóxeno não parece estar interessado, como Platão e Aristóteles, na questão do èthos musical. Aristóxeno (...) explicitamente recusa que o estudo da harmonia pudesse melhorar o espírito ou o caráter de alguém (Harm. 31.16-29 Meibom = 40.12-41.2 Da Rios)”16. Assim, o

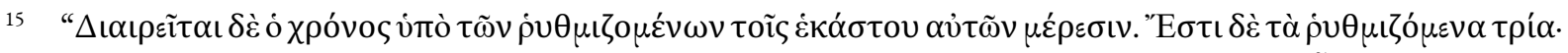

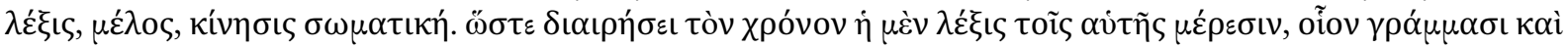

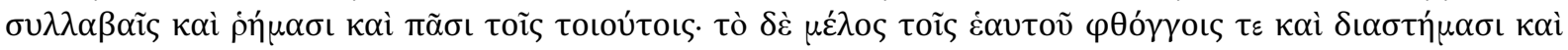

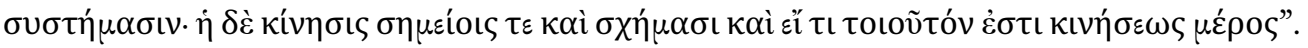

16 “(...) nor Aristoxenus seem to be as interested as Plato and Aristotle were in the issue of musical èthos. Aristoxenus, (...), explicitly denies that the study of harmonic science can improve anyone's soul or character (Harm. 31.16-29 Meibom = 40.12-41.2 Da Rios)".
} 
autor observa (ibidem) que a questão ética está restrita a um senso mais técnico, com referência às características próprias de uma escala ou melodia. Nesse sentido, a faculdade da percepção (aisthếseōs

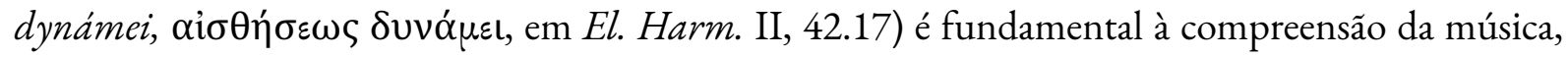
em detrimento de uma virtude. Por isso, reitera-se que um bom músico deve ter um pensamento crítico compatível a um bom ouvido.

Ainda em relação à percepção temporal, vale ressaltar que, em seus Elementos de Ritmo, o

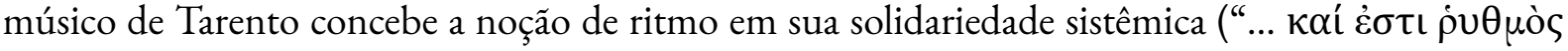

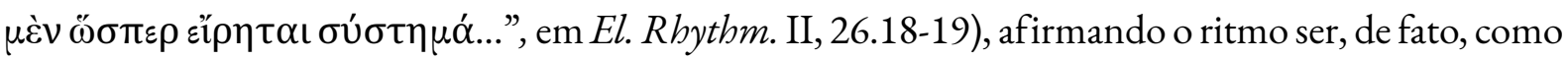

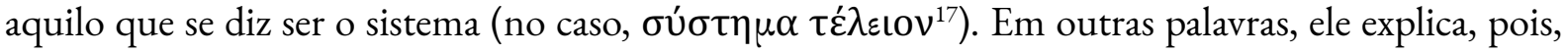

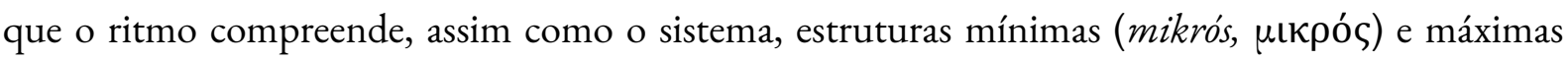
(mégas, $\mu \varepsilon ́ \gamma \alpha \varsigma$ ), em ampla extensão (mégethos, $\mu \varepsilon ́ \gamma \varepsilon \theta o \varsigma)$. Ou seja, o sýstēma está relacionado, a efeito, a todos os parâmetros da música, não apenas a alturas, como se concebe tradicionalmente.

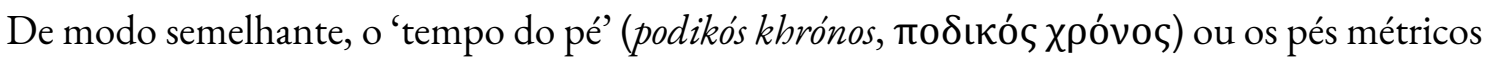
estabelecem uma comparação com os pés ou os passos cadenciados do movimento do corpo. No entanto, a relação metafórica entre os termos não permite dizer que haja, por isso, uma igualdade entre poesia (pés métricos), dança (passos, pés) e música (passo, compasso, andamento). Embora os termos sejam sinônimos de duração, extensão ou medidas temporais, não possuem o mesmo valor porque compreendem sistemas absolutamente distintos. Não é fortuito que Aristides Quintiliano (De Mus., I, 13.7), no século III ou IV d. C., tenha compreendido a importância do sistema para Aristóxeno, escrevendo que "o ritmo, por conseguinte, é um sistema de tempo disposto sob alguma ordem, e esta qualidade envolve as relaçóes de ársis e tésis, som e pausa”"

Ainda sobre essa questão, é verdade que metáforas nascidas no contexto de uma área podem, igualmente, migrar ou desdobrar-se a outras áreas, constituindo conceitos novos ou similares, como

\footnotetext{
17 Em Aristóxeno, sistema máximo sempre sob contexto poiético-prático. Portanto, sýstēma (systema, em latim;

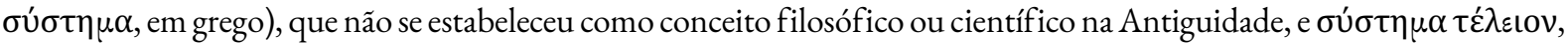
que deu origem ao conceito moderno de sistema, são duas acepçôes que devem ser diferenciadas. Sob esse viés, somente

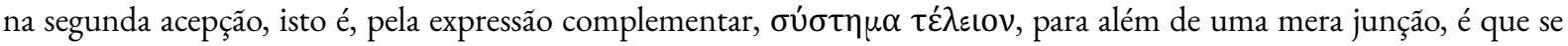
pode compreender sistema em um sentido epistemológico mais preciso. Por ser já uma estrutura de relaçôes articuladas,

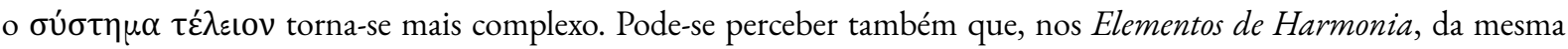
forma que as notas articulam-se sob sistema completo, nos Elementos de Ritmo, o ritmo também é uma potência sistêmica. Ou seja, os elementos musicais funcionam sempre em solidariedade, daí suas funçóes (rítmicas, harmônicas etc.).

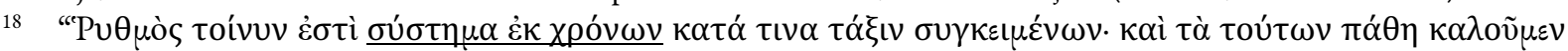

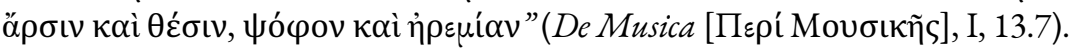


é o caso de "pés", quer métricos quer rítmicos ${ }^{19}$, em analogia ao passo da dança, em coreografia, outra palavra de plurirrelaçóes. Com muito cuidado de triar conceitos e de estabelecer-lhes o sentido em relação aos elementos do sistema, o músico de Tarento evitou muitos equívocos epistemológicos, principalmente em se tratando de conceito pouco indistinto entre áreas, não permitindo haver, em sua teoria, qualquer tipo de lacuna.

A fim de ilustrar equívocos advindos da falta de tratamento semântico em áreas distintas, podese refletir, brevemente, sobre a comparação, tradicionalmente consensual, entre o sistema de vogais longas e breves das línguas antigas ${ }^{20}$ e o sistema rítmico da música, com destaque às figuras. A paridade entre o sistema de quantidade vocálica, próprio do grego e do latim, e o de duração de notas provocou, por exemplo, a mistura da noção de pés métricos e prolação rítmica. A generalização conceitual ocorre, na verdade, pela falta de compreensão dos elementos de um sistema, isto é, de seu modus operandi, principalmente quando se dista das fontes filosóficas primárias, sob risco de esquecimento das relações analógicas ou metafóricas para a disposição nominal das expressões rítmico-musicais. Esse esquecimento epistemológico resulta no esquecimento da poiessis.

A indistinção epistemológica entre artes culmina em produções de récitas de poesia antiga que confundem dados de prosódia com solfejo de partitura, tendo em vista que vogais longas e breves não podem ser, acusticamente, meio tempo em relação a tempo inteiro, a despeito de uma vogal longa corresponder à duração de duas breves e, por sua vez, uma breve equivaler à metade de uma longa. Se acusticamente considerado, pode-se transformar uma declamação em sequências de batida esdrúxulas a qualquer sistema linguístico, contra a naturalidade da dicção e do ouvido. Posto em termos de figuras, longas e breves não corresponderiam, por exemplo, a semínimas e colcheias, a não ser que

19 A não diferenciação entre pés métricos e figuras rítmicas pode resultar em equívocos sobre poesia e música. Da mesma forma, buscar semelhanças entre quantidade de vogais e figuras rítmicas é tão problemático quanto considerar que, na dança, haja uma igualdade entre passos e tonicidade linguística. Claro, é permissiva a comparação metafórica, bem como seus desdobramentos, se garantida a distinção entre sistemas. Não se trata de um problema de nomenclatura em si, mas quer de espelhamento conceitual quer de desfiguração de sistemas. Assim, é de todo inútil a teoria que se equivoca quanto a um conceito ou que não respeita a natureza de um sistema.

20 Neste artigo, toma-se o latim como referência ao fenômeno da quantidade vocálica nas línguas antigas. No caso, as longas e breves são vogais que se distinguem por oposição fonológica, em solidariedade ao sistema morfossintático. Como o dado acústico perdeu-se há muitos séculos, hoje havemos de nos valer de convenções de escrita e de pronúncia, em uma tentativa artificial de conceber essas oposições. Sabe-se, em resumo, que há, na língua latina, dez vogais: a, e, i, o, u longas e breves (independentemente do que tenha sido sua pronúncia, se é que tenha havido uma distinção necessariamente acústica entre todas as suas vogais). Igualmente, tentar encontrar resquícios de vogais longas e breves em línguas modernas é, de fato, uma tentativa forçosa de espelhar-se nos antigos gregos e romanos. 
insistamos equivocadamente em uma pronúncia trauteada a ouvidos que desejam mais do que uma lição de solfejo.

Sobrepujar o sistema métrico-poético e rítmico-musical, forçando-lhes igualdades, é um dos principais problemas no tratamento da arte antiga, muitas vezes fadada a desastrosas declamaçóes hipotéticas, que, sob argumento histórico, ao invés de reconstruírem a arte musical grega ${ }^{21}$, afastamse dela porque se aproximam, na verdade, da Kulturindustrie (Indústria da Cultura), termo cunhado pelo filósofo Theodor Adorno (1903-1969), juntamente com Max Horkheimer (1895-1973), entre

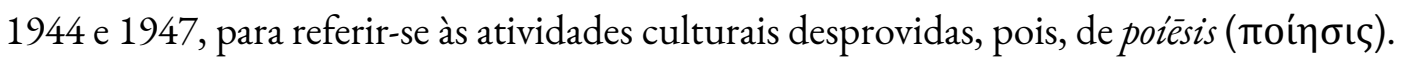

Em relação ao sistema vocálico de línguas antigas, o latim, por exemplo, composto por dez $\operatorname{vogais}(\mathrm{a}, \mathrm{e}, \mathrm{i}, \mathrm{o}, \mathrm{u} \text {, longas e breves })^{22}$, não tem paridade com o sistema de duração musical, cuja notação é bem mais tardia. São sistemas distintos que se valem de convençôes grafológicas também distintas, que, aliás, os antigos desconheciam. A confusão de nomenclatura, que imputa às línguas modernas a noção de longas e breves ${ }^{23}$, sugere aproximações arbitrárias entre sistemas linguísticos.

A indistinção epistemológica para sistemas diferentes dificulta a compreensão de fenômenos linguísticos e artísticos e por limitar a concepção de sistema. Por essa razão, a triagem epistemológica deve ser um processo primário no exercício do pensamento, em qualquer área. Outrossim, é legítimo o cuidado de Aristóxeno em organizar, mediante distinção, a episteme musical, para então iniciar suas reflexões acerca de harmonia e de ritmo, estabelecendo o pensamento filosófico-musical sob coerência terminológica. Em suma, a quantidade ou a duração de vogais não pode corresponder necessariamente ao tempo de emissão sonora das notas musicais, a não ser que se queiram aproximaçôes arbitrárias. Logo, há de se diferenciar a quantidade vocálica da duração rítmica.

21 Com exceção de escassos dados, a arte musical grega foi praticamente perdida; diferentemente, há bem mais informaçóes sobre a teoria musical grega, a que ainda temos acesso, muito graças aos estudos de Aristóxeno, perpetuados principalmente por seus epígonos e pela Idade Média e Renascimento.

22 Essas distinções fonológicas não exigem, necessariamente, uma coincidência físico-acústica, por assim dizer. Afinal, a língua opera por meio da cognição, sendo, nesse sentido, sempre virtual e formal (sempre forma, nunca substância), conforme Saussure (1969). "No fundo, tudo é psicológico [virtual] na língua, incluindo suas manifestações materiais e mecânicas, tais quais as alteraçóes dos sons" (SAUSSURE, 1969, p. 21). ["Au fond, tout est psychologique dans la langue, y compris ses manifestations matérielles et mécaniques, comme les changements de sons"].

23 É possível encontrar gramáticos (sem menções aqui) que afirmem haver vogais longas e breves, ou mesmo resquícios delas, em algumas línguas atuais, como o alemão, o italiano e o japonês, dentre outras. Na verdade, confunde-se o que é próprio do sistema de línguas antigas - diga-se, em sincronias passadas - com o sistema moderno. Há, notadamente, possibilidades de equivalência, mas nunca uma igualdade (Cf. THAMOS, 2011, passim). 


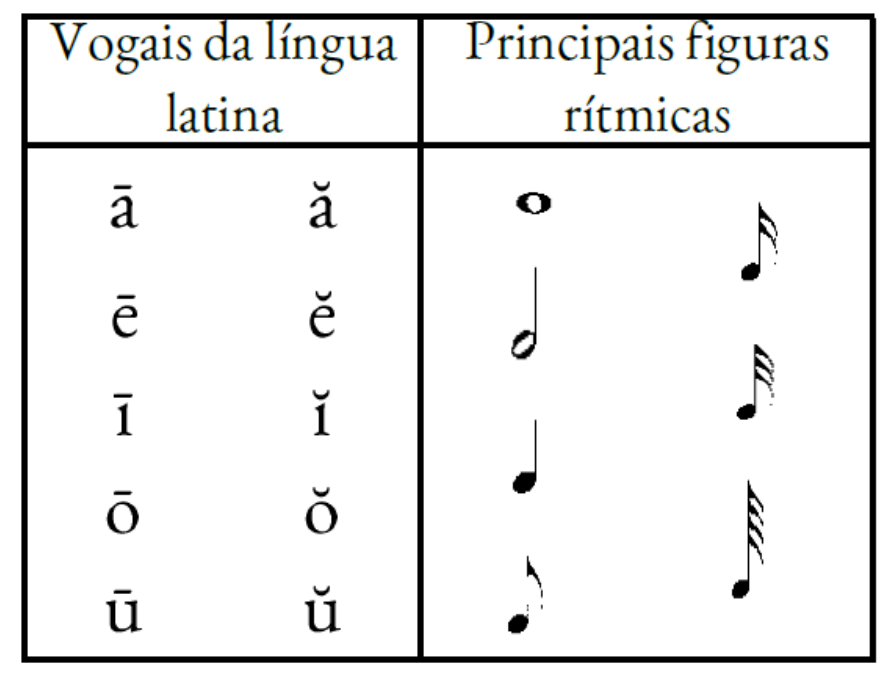

Fonte: elaborado pelos autores (2021).

Em se tratando de indistinção conceitual entre sistemas de linguagem, semelhante fenômeno ocorre com a terminologia do sistema métrico da língua inglesa moderna ${ }^{24}$, cuja estrutura prosódica é formada por sílabas tônicas ${ }^{25}$, e não por pés métricos, como nas línguas antigas. No entanto, ainda é usual, nos estudos literários, nomear os decassílabos de Shakespeare de 'pentâmetros jâmbicos' (iambic pentameter, em inglês), confundindo longas e breves com acento forte e fraco, tais quais a “batidas de tambor” - aqui já misturando duração da música, sistema métrico antigo e tonicidade das línguas modernas. Ao pé da letra, isso significaria que um 'pé jâmbico', em inglês, seria composto por uma sílaba breve ( ${ }^{`}$ ) ou átona e uma sílaba longa $\left(^{-}\right.$) ou tônica, no esquema: $\left.\right|^{\sim}{ }^{-} \mid$.

Abaixo, dispõe-se, com intuito de ilustração, o soneto 13 do escritor inglês William Shakespeare (1564-1616), a partir de sua edição fac-símile de 1609. O poema é composto por 14 versos, sendo os dois últimos um dístico. Ou seja, os três quartetos encerrados por um dístico configuram a estrutura básica de um soneto inglês. No exemplo a seguir, o tema fundamental encontra-se na oposição entre vida e morte a partir da permanência da juventude pela continuidade das gerações. Sugere-se, assim,

\footnotetext{
24 Agradece-se ao Prof. Dr. Márcio Thamos pelas conversas profícuas que estimularam essas reflexões sobre métrica. Também, destacam-se, em apreço, os estudos essenciais de Alceu Dias Lima (1995).

25 Tonicidade. Por isso, no processo prosódico, incluindo a composição de canções, é importante diferenciar os sistemas linguísticos do latim e do português - que são, evidentemente, distintos. No latim, vigora a quantidade; no português, a tonicidade.
} 
que a beleza ou o "doce semblante" possa ser passado a outrem pelo legado da descendência, única possibilidade de vencer a improvidência e a raiva infértil da morte fria. Nesse sentido, enquanto houver reprodução humana, sempre existirão, no mundo, a beleza e a juventude. Trata-se, pois, de uma topica ${ }^{26}$ shakespeariana. Em outras palavras, o amor entre as gerações é capaz de vencer até a morte, pois permite que a beleza da juventude permaneça sempre viva, legado das gerações.

\author{
O That you were yourselfe, but love you are \\ No longer yours, then you yourselfe here live, \\ Against this cumming end you should prepare, \\ And your sweet semblance to some other give. \\ So should that beauty which you bold in lease \\ Find no determination, then you were \\ Yourselfe again after yourselfes decease, \\ When your sweet issue your sweet forme should beare. \\ Who lets so faire a bouse fall to decay, \\ Which husbandry in honour might uphold, \\ Against the stormy gusts of winters day \\ And barren rage of deaths eternall cold? \\ O none but unthrifts, deare my love you know, \\ You had a Father, let your Son say so.
}

(Shakespeare, Sonnet 13).

Tradicionalmente, o esquema métrico por que se organiza o soneto acima é nomeado de pentâmetro jâmbico ou, em inglês, iambic pentameter. Trata-se, notadamente, de uma nomenclatura aplicada a línguas cujo sistema métrico esteja embasado em pés, tais quais o grego e o latim. O inglês moderno, como é o de Shakespeare, não se estrutura por pés, mas por tonicidade, como ocorre com o português, o espanhol, o francês, o italiano, dentre outras línguas. A noção de pentâmetro corresponderia a um verso formado por cinco pés métricos. Já o jambo, que constitui o pé jâmbico, compóe-se por uma vogal breve e uma longa ( ${ }^{-}$). Sob esse viés, imputando aos versos shakespearianos pentâmetros jâmbicos, escandiríamos forçosamente o poema da seguinte maneira, valendo-se dos quatro primeiros versos como exemplo:

\footnotetext{
26 Empresta-se da Retórica o conceito de tópica, no sentido de lugar-comum (Aristóteles, Ret., 1416b, sob a expressão

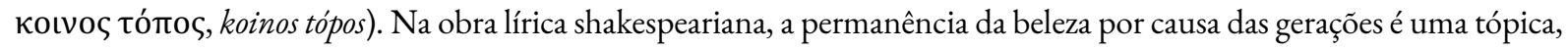
em que se sugere a perpetuação.
} 
FIGURA 3 - Escansão dos quatro primeiros versos do Soneto 13, de Shakespeare, sob esquema de pés métricos.

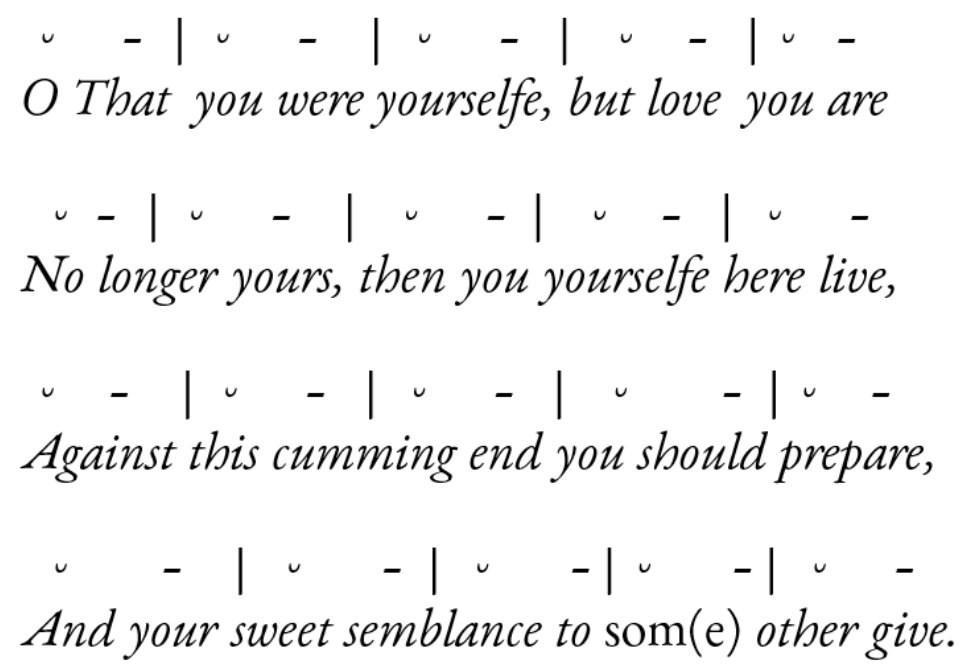

Fonte: Os autores (2021).

No entanto, o inglês não é composto por vogais longas e breves. Em seu sistema vocálico, não há longas ou breves, nem pés, assim como no português. Ou seja, um pé jâmbico não pertence ao sistema métrico-prosódico do inglês. Para manter a mesma terminologia das línguas grega e latina, convertem-se forçosamente a vogal breve em vogal átona e a vogal longa em tônica, a despeito de duração não significar tonicidade. Em outras palavras, uma longa não corresponde necessariamente a um tempo forte ou inteiro.

Considerando que a língua inglesa estrutura-se a partir de um sistema silábico-acentual e que ela não comporta pés métricos, é possível escandir um soneto shakespeariano de uma forma mais coerente em relação ao seu sistema, a qual veria nos metros do bardo inglês, simplesmente, decassílabos ${ }^{27}$, ao invés de cinco pés jâmbicos (supostamente, tempo fraco e tempo forte). Assim, propóe-se a seguinte escansão:

27 O decassílabo é o verso constituído por dez sílabas poéticas, contadas até à última tônica (não são sílabas gramaticais). Notadamente, é um metro possível em línguas que tenham o sistema métrico baseado na tonicidade, mas impossível nas línguas que operam mediante quantidade vocálica. 
FIGURA 4 - Escansão do Soneto 13, de Shakespeare.

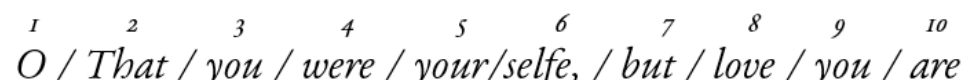

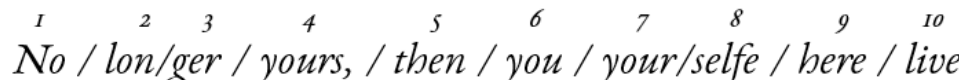

$\begin{array}{lllllllllll}I & 2 & 3 & 4 & 5 & 6 & 7 & 8 & 9 & 10\end{array}$

A/gainst / this / cum/ming / end / you / should / pre/pare,

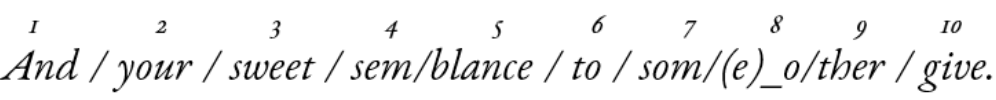

${ }_{\text {So / should / that / beau/ty / which / you / bold / in / lease }}^{2}$

Find / no / de/ter/mi/na/tion, / then / you / were

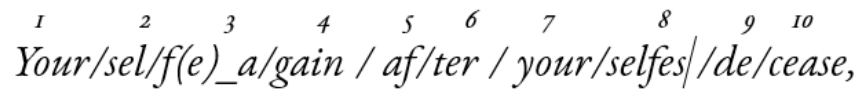

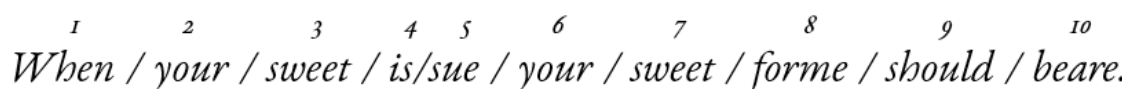

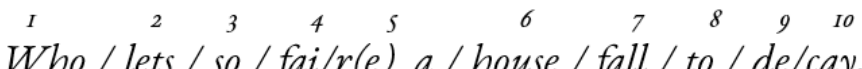

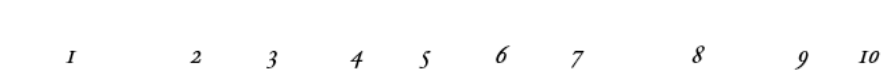

Which / bus/ban/dry / in / bo/nour / might / up/bold,

$\begin{array}{lccccccccc}I & 2 & 3 & 4 & 5 & 6 & 7 & 8 & 9 & \text { Io }\end{array}$

A/gainst / the / stor/my / gusts / of / win/ters / day

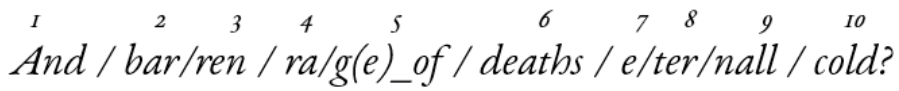

$\begin{array}{lllllllllll}1 & 2 & 3 & 4 & 5 & 6 & 7 & 8 & 9 & \text { Io }\end{array}$

O / none / but / un/thrifts, / deare / my / love / you / know,

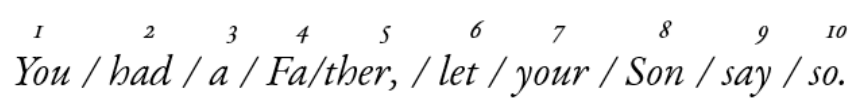

Fonte: Os autores (2021).

Nota-se, nos versos acima, a presença de decassílabos predominantemente heroicos, cujo auge tônico recaia na sexta e na décima sílabas poéticas. Ademais, dentre outras possibilidades expressivas, recursos de elisão vocálica propiciam sugestões sonoras que contribuem à temática do poema. Porém, não é fulcro deste estudo desenvolver uma análise literária desse soneto inglês. 
Caso fosse possível declamar pentâmetros jâmbicos, entendidos equivocadamente como cinco sequências de fraco e forte, à semelhança de um tambor (o que é inimaginavelmente forçoso), a leitura resultante seria de uma prosódia em solavancos, desastrosa à percepção artística, que sempre deseja a naturalidade de uma língua, ainda mais na boca de um grande ator. A inventividade artística dos versos de Shakespeare estaria fadada, pois, a um efeito rítmico imensurável, que não perceberia o engenho da composição, em se tratando de combinaçôes poéticas entre plano de expressão e de conteúdo. Afinal, tentar encontrar no sistema de línguas modernas vogais longas e breves é uma proposta que não procura nem superar o sistema, nem o compreender, senão desfigurá-lo, isenta uma postura reflexiva sobre a linguagem.

A despeito das tentativas que se façam (e que serão sempre irremediavelmente artificiais), para nós, falantes das línguas atuais, vale dizer, dessas de sincronia aberta, é impossível reproduzir com um mínimo de verdade formal - a única que pode interessar ao se considerar uma língua - a distinção entre vogais longas e breves, cuja oposição não motiva traços fonéticos e fonológicos das nossas línguas (LIMA; THAMOS, 2005, p. 127).

Em relação ao inglês moderno, língua materna de falantes vivos, percebemos sensorialmente muito bem a qualidade artística de decassílabos heroicos, em prosódia natural - e inventiva! - ao sistema. Mas o que seria a cadência natural de hexâmetros datílicos ${ }^{28}$ de que, por exemplo, Virgílio, no século I a. C., valeu-se na composição de sua Eneida? Ou então, o que pensar sobre a pronúncia das vogais latinas cujo sistema fonético-fonológico divide-as em longas e breves? Na verdade, sabemos muito pouco. Há de se admitir o estado de ruínas em que se encontram os dados acústicos dessa língua antiga tão viva.

Modernamente, no entanto, as unidades de medida do hexâmetro só são reconhecíveis numa contagem metalinguística que, diante da impossibilidade completa de se coletarem dados empíricos, leva em consideração tão-somente noçóes teóricas, isto é, escolares. Assim, os pés métricos latinos só podem ser apreendidos de forma estritamente intelectual, sem nenhum outro fundamento que advenha da percepção física motivada pela expressão oral que ao verso possa emprestar a voz de qualquer leitor, seja este mesmo o mais erudito e reconhecidamente preparado no trato com essa língua antiga (LIMA; THAMOS; 2005, p. 129).

28 Hexâmetros datílicos são versos compostos por seis pés métricos, sendo o quinto sempre um dátilo (uma longa e duas breves, no esquema $\left.\right|^{-}{ }^{-} \mid$e o sexto um troqueu $\left(^{-}\right.$) ou um espondeu $\left(^{--}\right.$). 
Se as condições acústicas e materiais das línguas grega e latina encontram-se historicamente comprometidas, o que poderíamos dizer, também, das tentativas de reconstrução de obras musicais antigas, que af irmam serem historicamente informadas, sem nenhum suporte grafológico que possa orientar o ouvinte contemporâneo na reconstituição da atividade da poiésis musical? Se esse impasse já é nosso em relação, por exemplo, ao século XVIII, quanto dizer sobre as canções homéricas?

FIGURA 5 - Detalhes de colunas romanas com parte do Coliseu ao fundo, a partir da Via Sacra, em Roma, na Itália.

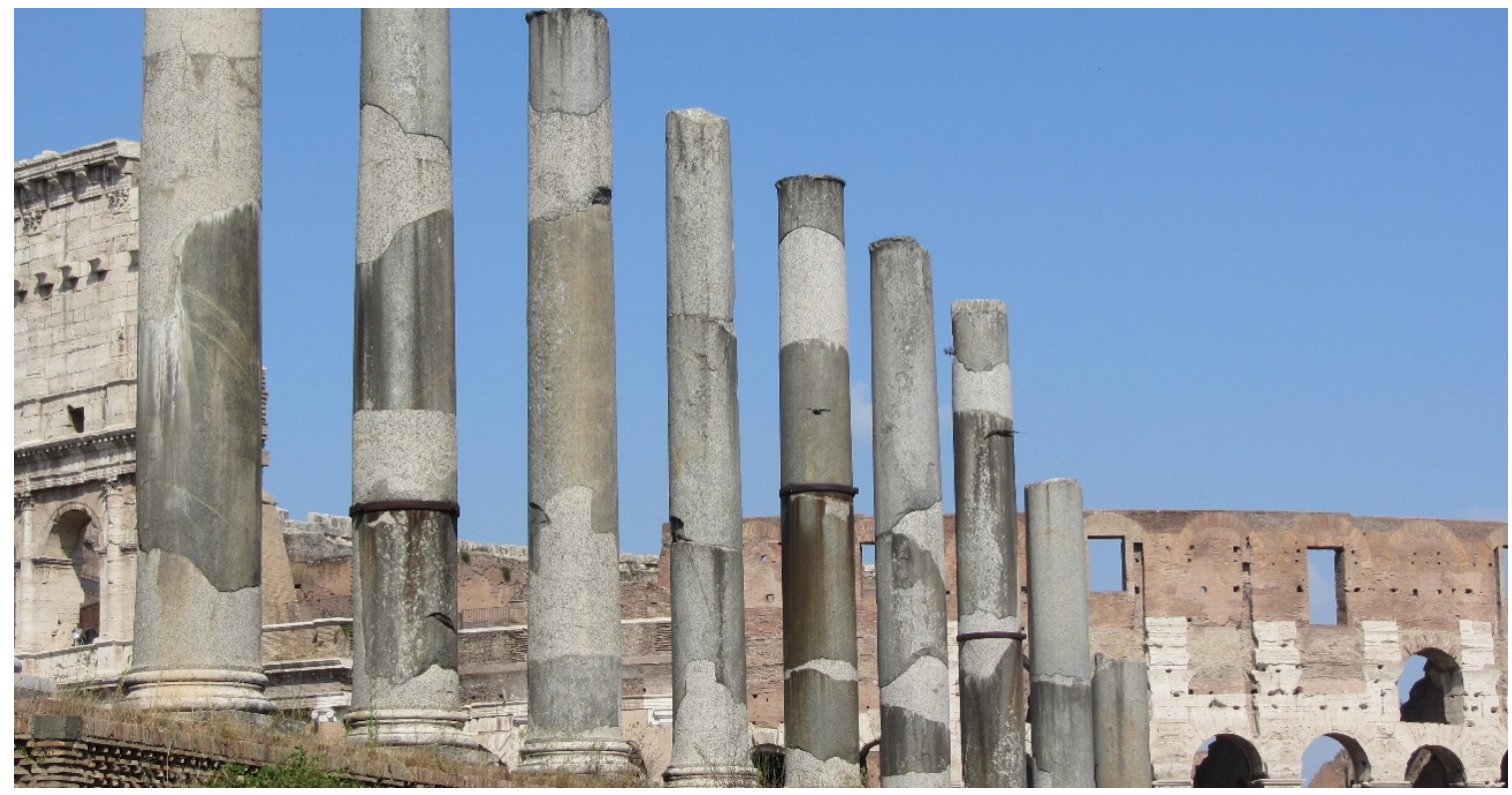

Fonte: arquivo pessoal (2021).

A confusão epistemológica acarreta, dessa forma, em retrocessos na compreensão da arte musical e poética, em que não se distinguem sistemas modernos e antigos, nem sistemas de linguagens distintas, quer a poética, quer a musical. Ainda, sequer apontamos a consequência dessas confusóes epistemológicas no exercício da tradução, quando há o intento de manter, de uma língua antiga a uma língua moderna, um padrão métrico idêntico, resultando, na verdade, em um esdrúxulo metro, próprio de nenhuma língua. Ou seja, também a práxis tradutória, sem a triagem epistemológica e a reflexão, esquece-se da poiésis. Destaca-se, pois, a preocupação constante de Aristóxeno - quem assentou, de fato e pela primeira vez, a teoria musical - em triar todo e qualquer conceito passível de sistematização.

O problema que se levanta é que a indiferenciação de elementos de sistemas distintos, tais quais o métrico e o rítmico, mesmo em homologias, deturpa a recepção de música e poesia antigas. Essa 
preocupação não é própria da literatura ou dos estudos clássicos, mas incide, inclusive, na consciência do compositor em seu métier, ao musicalizar poemas, e na execução do intérprete, enquanto performance, isto é, a práxis de uma poiessis. Por isso, a incompreensão de métrica e de rítmica pode resultar em uma má execução, seja do ator, seja do musicista, imprimindo no sistema linguístico cadências e marcaçóes rítmicas não naturais ao sistema, por conseguinte, esquecendo-se da poiêsis ao declamar ou a compor. Por essa razão, dentre outras questôes, são importantes as distinções nocionais e operacionais de um sistema. Reafirma-se, nesse sentido, que longas e breves não significam vogais tônicas e átonas, tampouco semínimas e colcheias.

Qualidades dos sons vocálicos tão fundamentais em português quanto o timbre e a intensidade não têm valor distinto apreciável em latim clássico, em que, por contrapartida, está em vigor uma propriedade tão neutra em línguas românicas como a quantidade, cuja representação só é hoje possível por procedimentos gráficos ou por exageros de prolação impraticáveis, porque incompatíveis com o caráter oral de qualquer língua falada (...) (LIMA, 1995, p. 48).

Se a noção de quantidade do grego e do latim serviu como parâmetro ao estabelecimento de algumas nomenclaturas rítmicas na música, o contrário não é verdadeiro. O equívoco não se encontra no aproveitamento de léxicos interartísticos, senão de inferências casuais. Nesse sentido, se é verdade que o estabelecimento da prolação musical pela Ars antiqua $^{29}$, por exemplo, tomou como inspiração a oposição entre longas e breves, como um facilitador terminológico por assim dizer (o que é genuíno), no entanto, não é verdadeiro dizer que o sistema rítmico-musical e o prosódico-métrico operam da mesma maneira. Ou seja, se a ideia de longas e breves serviu ao estabelecimento de algumas convençôes rítmicas na música, sob senso análogo ou metafórico, não se pode afirmar o contrário. Outrossim, a quantidade vocálica não tem articulação rítmica acusticamente determinada, ainda mais em relação à disposição gráfica das notas musicais (confundindo-se forma e substância). Essa relação seria, pois, bem fortuita.

\footnotetext{
29 Ars antiqua ou Ars vetus (séculos XII e XIII) foi um termo historicamente estabelecido a partir do século XIV, a fim de caracterizar um período particular da teoria e composição musicais, haja vista o período seguinte, denominado Ars nova. Uma das preocupações da arte antiga é a resolução de questões de notação musical, principalmente quanto à rítmica, além de nuances melódicas. A principal escola musical surgiu em função das obras teórico-musicais dos compositores franceses da Notre Dame de Paris, com destaque ao gênero composicional organum, voltado a mesuras rítmico-modais da música litúrgica, bem como ao estabelecimento de relações contrapontísticas e polifônicas (ROESNER, 2016, passim).
} 
Logo, encontrar prolação musical em vogais é tão problemático quanto correspondências entre cores e passos de um bailarino, como se fossem sistemas únicos ou iguais. A diferença entre dança e pintura, notadamente, é bem visível. Com isso, não se quer afirmar que seja impossível estabelecer equivalências terminológicas entre áreas, contanto que não se desfigure o sistema. $\mathrm{O}$ nome, pois, em sua importante limitação semântica, não pode alterar as funçôes dos elementos de um sistema.

Partindo desse raciocínio, entende-se que uma noção pode ser comum a distintos sistemas, mas a sua especificidade semântica pode ser atribuída somente em função dos elementos ou da natureza de um sistema em específico. Portanto, um conceito geral, que não serve a nenhum sistema em específico, é, pois, assistemático, tornando-se, de fato, inteligível a partir de uma clara delimitação. Caso não haja a especialização semântica, não há episteme cognoscível. Por exemplo, a noção de tempo é assistemática, se não considerada em função de uma especificidade, quer um contexto, quer uma relação de elementos de algum sistema. Já a noção de duração musical é o tempo nesse sistema, uma vez que haja elementos em função, relação ou interação. Já a composição artística, em outro patamar, vale-se dos elementos de um sistema em função, já sistematizados, mas em arranjo inventivo

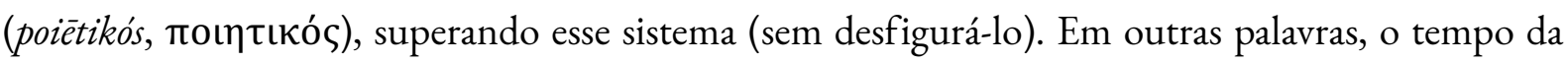
música não é o mesmo da poesia, pois recebem tratamentos diferentes em função da natureza de cada sistema. Trata-se, afinal, de percepções distintas. A contextualização epistêmica é fundamental à base do pensamento, senão atribuiríamos o mesmo fenômeno - o tempo - a uma propriedade geral, em teor assistemático. Em outras palavras, quando se misturam conceitos em sistemas distintos, não se trata de equivalências epistemológicas, mas de uma competição forçada por igualdade sistêmica. Em suma, as especificidades nocionais de um sistema respeitam a sua natureza e o seu funcionamento.

Ainda em relação à Ars antiqua, quando possivelmente Jobannes de Garlandia ${ }^{30}$ (1270-1320) escreveu ou editou as obras sobre a mensura das notas musicais, a fim de estabelecer a música proporcional, apoiou-se na nomenclatura da quantidade vocálica das línguas antigas para o estabelecimento de certas estruturas temporais estanques, os modos (modi). No caso, por uma questão terminológica, adotaram-se os termos "longa" e "breve" como oposição de base a estruturas rítmicas da música monódica mensurável (musica mensurabilis), nominada órganon (organum),

30 Não confundir com o gramático de mesmo nome, João de Garlândia (1180-1252), autor de Parisiana Poetria. 
expressão aplicada a toda música mensurada ${ }^{31}$. Por assim dizer, a ideia de longas e breves serviu de modelo para determinar padróes rítmico-musicais, estabelecendo, pois, um vocabulário rítmico. Assim, foram fixados valores temporais, tendo em vista também convençôes de escritas.

Por essa razão, a Ars Antiqua procurou constituir os ritmos modais a partir da oposição entre a longa (longa) - como um tempo inteiro - e a breve (breuis) - metade dele. Dessa forma, a ideia foi que os padróes rítmicos, aqueles previamente estabelecidos, obedecessem a determinadas disposiçôes de sequências entre tempos inteiros e meios, com predileção a uma percepção ternária, variando a partir dos neumas virga (longa) e punctus (breve), contendo três semibreves (ANDRADE, 2015, p. 24). "É chamado de espécie [ou modo] o som que se apresenta sob mesma medida de tempo, de certo, mediante longas e breves” ${ }^{32}$ (Garlandia, De Mus., 36).

Com essas unidades, foram estabelecidos os modos, configurando a música mensurada, que se vale desses tipos determinados a partir de longas e breves. Em De musica mensurabili positio (97), explica-se a respeito dos modos rítmicos:

Disse João [de Garlândia], tendo considerado o estudo sobre o cantochão e sobre todos os tipos de sons, dividindo-os em altura e duração, chamados, por nós, de modo do som. Nele, o modo é o exame do som em agudo e grave; também de acordo com o prolongamento ou encurtamento do tempo. Ademais, pode-se tomá-lo de duas maneiras, quer comum quer próprio. O modo comum é aquele que se volta ao prolongamento e ao encurtamento de todos os sons; já o modo próprio é o que se volta aos seis modos antigos. ${ }^{33}$

Dessa forma, João de Garlândia posiciona-se sobre a música medida, buscando compreender a natureza dos sons em duração e altura (extensão horizontal e vertical), a partir, principalmente, dos modos rítmicos. No caso, eles se constituem, portanto, a partir de sua percepção quanto à duração e à altura. Ademais, sendo o som não restrito ao padrão dos seis modos antigos, ele é comum; senão, é

\footnotetext{
31 "Tendo já considerado a música plana [cantochão], que chamamos de imensurável, agora convém tratar daquela mensurável, a que chamamos de órganon, uma vez que dizemos órganon, em geral, a toda a música mensurável.” "“Habito de ipsa plana musica, quae immensurabilis dicitur, nunc est praesens intentio de ipsa mensurabili, quae organum quantum ad nos appellatur, prout organum generaliter dicitur ad omnem mensurabilem musicam." GARLANDIA, 1864 [1240?], p. 175).

32 "Maneries eius appellatur, quidquid mensuratione temporis, videlicet per longas vel per breves, concurrit."

33 "Habito, inquit Johannes, de cognitione plane musice et omnium specierum soni, dicendum est de longitudine et brevitate corumdem; que apud nos, modus soni appellatur. Unde modus est cognitio soni in acuitate et gravitate, secundum longitudinem temporis et brevitatem. Et potest dupliciter sumi; aut communiter aut proprie. Modus communis est qui versatur circa omnem longitudinem et brevitatem omnium sonorum. Modus proprius est qui versatur circa VI modos antiquos." (Garlandia, De Mus., 97).
} 
próprio ou específico, tendo em vista a relação entre longas e breves para as notas. Em relação aos seis modos rítmicos, Garlândia (De Mus., 91) afirma que, desses modos,

o primeiro consta de uma longa e uma breve, uma longa e uma breve etc.; o segundo, de uma breve e uma longa, uma breve e uma longa; o terceiro, uma longa e duas breves, uma longa e duas breves etc.; o quarto, duas breves e uma longa etc.; o quinto, todas longas; o sexto, todas breves. ${ }^{34}$

Em outras palavras, pode-se resumir que uma longa e uma breve configuram o modo primeiro; uma breve e uma longa, o segundo; uma longa e duas breves, o terceiro; já duas breves e uma longa, o quarto; duas longas somente, o quinto; por fim, três breves, o sexto. Há uma relação lógicacombinatória em função das possibilidades de arranjos dos modos. Ademais, cada modo pode ser repetido quantas vezes necessárias até uma pausa. Em acréscimo, aponta-se que Walter Odington (1280? - 1330?), já da tradição inglesa, diferentemente de Garlândia, chegou a comparar determinadas combinaçôes rítmicas estanques a pés métricos, haja vista termos como dátilo $\left({ }^{-}\right)$, espondeu $\left(^{-}{ }^{-}\right)$e troqueu $(-\smile$ ), próprios dos sistemas das línguas clássicas.

É importante dizer que Johannes de Garlandia, em nenhum momento, confundiu as sequências rítmicas com pés métricos, valendo-se do termo longa e breve como inspiração terminológica para a oposição de base rítmica, sem que se alterem ou confundam os sistemas de vogais e de notas musicais. O problema está, principalmente, na associação de longas e breves a durações acústicas determinadas, muito comum na práxis atual de estudo e de tradução de poesia e música antigas $^{35}$. Portanto, o assunto que se ventila é a confusão entre semínimas e colcheias e longas e breves, já uma relação forçosa a ambos os sistemas e arbitrária por concepção. Essa relação não seria plausível a um compositor ou tradutor que quisesse buscar, equivocadamente, igualdade entre sistemas (Cf. THAMOS, 2011, passim).

\footnotetext{
34 "[Quorum modorum] primus constat longa brevi, longa brevi, etc. Secundus brevi longa, brevi longa. Tercius longa duabus brevibus, longa duabus brevibus, etc. Quartus duabus brevibus longa, etc. Quintus omnibus longis. Sextus omnibus brevibus.”

35 Por música antiga, entendemos a arte musical principalmente dos gregos e dos romanos, que, diferentemente da teoria, praticamente não conhecemos. O "antigo" não se refere à música da Idade Média, do Renascimento ou até do século XVII, já muito mais recente.
} 
FIGURA 6 - Espécies de modos (Compilado da obra de Garlandia, De mensurabili musica).

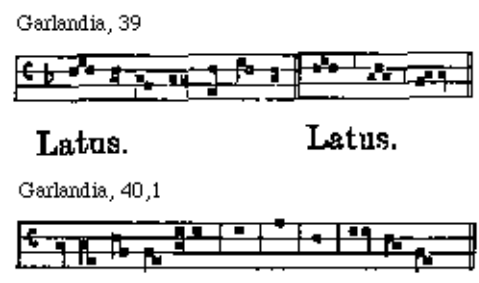

Fulminante, ut in Dic Christi. /

Garlandia, 41,1

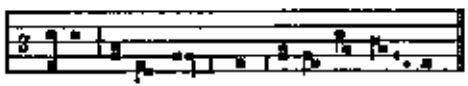

Et sperabit, in discantu Lone tans a.

Garlandia, 42,1

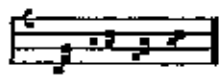

Regnat.

Garlandia, 43,1

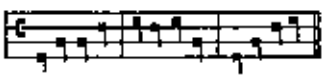

Laqucus.

Garlandia, 43,3

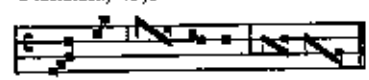

Et exaltavi.

Garlandia, 52,1

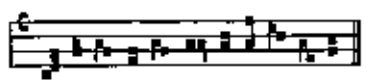

Angelus.

Garlandia, 53,1

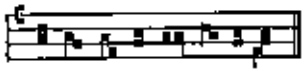

Balåm.

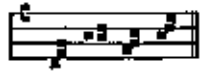

Regnat.

Garlandia, 52,2

Angelus.

Garlandia, 53,2

Balaam.

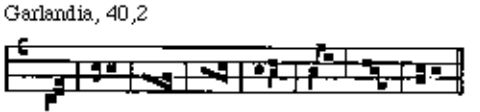

Angelus.

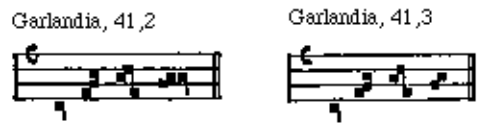

Regnat.

Regnat.

Garlandia, 42,3

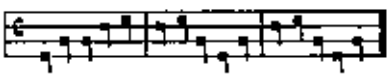

Laqueus.

Garlandia, 43,2

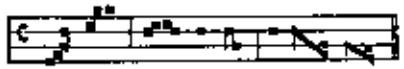

Et exaltavi.
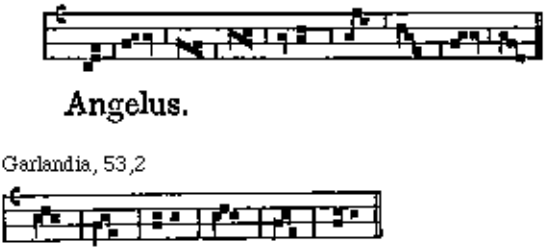

Fonte: Thesaurus Musicarum Latinarum (Online).

Naturalmente, Aristóxeno valia-se da equivalência terminológica entre ritmo, métrica e dança. No entanto, embora tenha se utilizado de alguns termos compartilhados também pela poesia e pela dança, em nenhum momento de seus tratados atestou igualdades entre sistemas distintos; pelo contrário, exigia de sua teoria clara distinção. Obviamente, embora se possa falar em pés ${ }^{36}$ (a rigor, termo da dança) na métrica, por exemplo, não signifique que as vogais sejam dotadas de membros inferiores e possam caminhar para frente ou para trás ou mover-se para cima e para baixo. Vale ressaltar

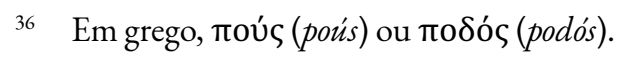




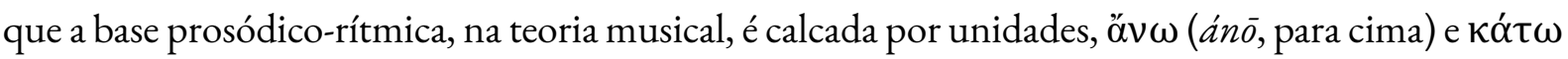
$(k a ́ t o ̄, \text { para baixo })^{37}$, em uma disposição metafórica com a dança, a fim de compor células rítmicas ou percepção rítmica.

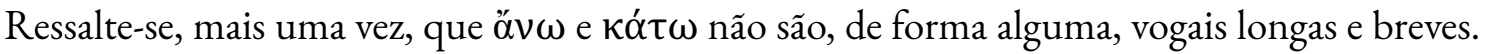
Porém, por analogia, as combinaçóes entre ambos os termos gerariam, ritmicamente, células que lembrariam algumas estruturas da poesia ou da dança, em relação a números (razôes, proporçôes, contagem), por isso se estabeleceu uma aproximação, antes de tudo, metafórica. Tomando emprestado alguns termos gerais entre sistemas, Aristóxeno (El. Rhythm., II, 24.16-16), ao definir os

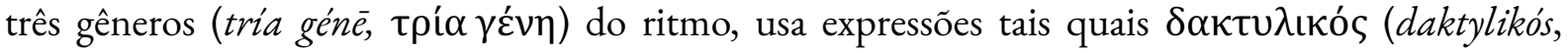

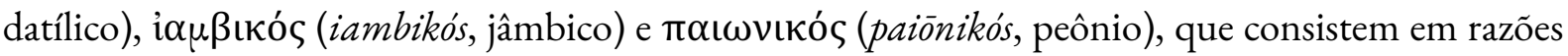

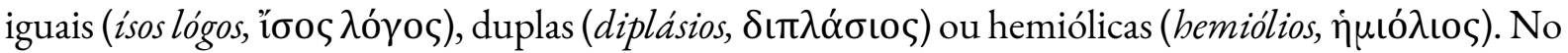
entanto, não são termos de igualdade à prosódia da língua grega; trata-se, na verdade, de expressóes

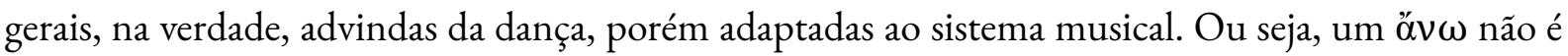
uma vogal breve, a qual não é um tempo fraco, nem uma colcheia. Vale reforçar que os antigos não conheciam as convenções gráficas de distinção entre longas e breves (os sinais representados pelo mácron e pela braquia). Em suma, esses empréstimos terminológicos entre áreas possuem seus limites semânticos haja vista a natureza dos sistemas.

Ainda em relação à Ars Antiqua, complementa-se que, embora Garlândia não tenha usado outros termos comuns na métrica, à guisa de nomenclatura, senão longas e breves, já Walter Odington enumerou-os com mais abundância, reflexo de uma influência anterior cujos primórdios encontramse em Censorino, Marciano Capela e Fulgêncio, dentre outros pensadores que se valeram de nomenclaturas latinas traduzidas do grego, inspirados em Aristóxeno, Aristides Quintiliano,

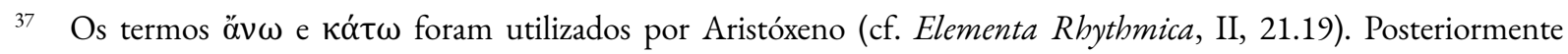

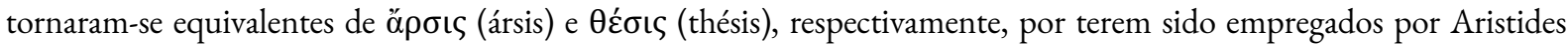
Quintiliano (De Musica, I, 13.14) em uma explicação metafórica entre ritmo e corpo (ő $v \omega$, portanto, corresponderia ao ato de levantar (ársis) uma parte do corpo, isto é, de suspender ou altear). Em Aristóxeno, ambos os conceitos, ánōe eáatō, representam unidades de tempo, em relação de contrariedade, passíveis de constituírem células rítmicas, binárias, ternárias e quaternárias, se em junções (sem correspondência exata com nossas convençôes gráficas atuais). "Dos pés [rítmicos], tendo em vista dois tempos correlacionados, há um tempo 'para cima' [ánō, ö $v \omega$, alteado] e outro 'para baixo' [kátō,

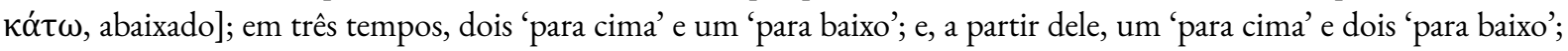

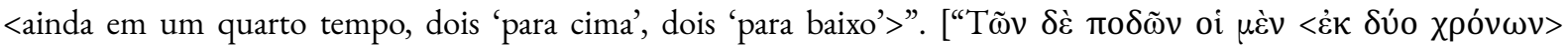

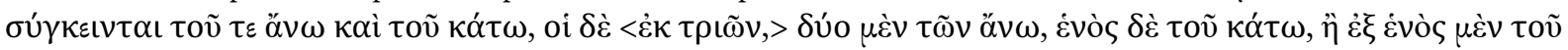

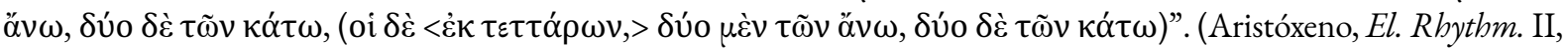
21.19-23)]. 
Cleônides e Ptolomeu. Em suma, propõe-se a distinção epistemológico-semântica de termos comuns entre sistemas, com destaque à diferença de prosódia entre línguas e à diferença entre métrica e ritmo, principalmente para o estabelecimento da prosódia musical, que incide diretamente na composição do canto. Ela exigiria, necessariamente, uma consciência quer do sistema musical quer do linguístico, ainda mais em se tratando de correspondências com o texto poético, cujo sistema métrico tem suas especificidades.

Tendo em vista uma tradição milenar da música associada à poesia, quer na tragédia grega antiga quer na ópera contemporânea, muito se discute a respeito das relações de sentido entre conceitos compartilhados em áreas distintas, como a música e a poesia. Além disso, considera-se a possibilidade sincrética de unir ambas as linguagens. Esse fenômeno pode ser observado no canto, que se vale da voz humana e que pode se utilizar de palavras. Assim surge o gênero canção, em síntese, um fenômeno predominantemente literomusical que se dispóe tanto do sistema linguístico quanto do sistema musical, em homologia, isto é, em solidariedade, passível, inclusive, de análise conjunta ou disjunta. Em outras palavras, a canção pode ser estudada sob ponto de vista estritamente musical, estritamente poética ou considerando ambas as estruturas em busca da relação, junção ou homologia entre as partes. Trata-se, afinal, de sobreposições de sistemas.

Conforme o pensamento do músico de Tarento, em síntese, a principal distinção entre canto e fala consiste no fenômeno da continuidade ou da descontinuidade da voz. Ou seja, quanto mais pontos estacionários, isto é, intervalos, mais próximo do canto; quanto mais movimento contínuo, sem ponto fixo, mais próximo da fala ou mais característico de fala. $\mathrm{Na}$ canção, é possível haver a sobreposição do sistema musical no sistema linguístico, em solidariedade inventiva. Nesse processo, pode-se perceber as relaçôes entre as linguagens em busca de homologias potencializadas por ambos os sistemas. Sob esse viés, aquilo que é substância de um sistema pode tornar-se forma a outro, em sobreposições, como é o caso da dicção do canto, em que variações fonéticas, tais quais alofones, podem se tornar um dado musical poeticamente expressivo.

Segundo Aristóxeno, a essência do pensamento que distingue a fala do canto consiste, pois, na natureza dos movimentos vocais. Definir as espécies de movimento, por continuidade e por intervalo, foi o primeiro passo para a resolução do problema epistemológico. Dessa forma, o filósofo grego da península itálica percebeu que, enquanto o canto deseja estacionar em regiôes determinadas, a fala 


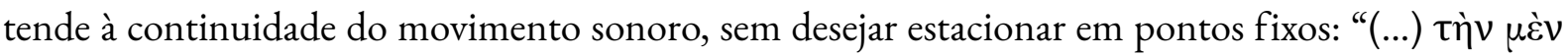

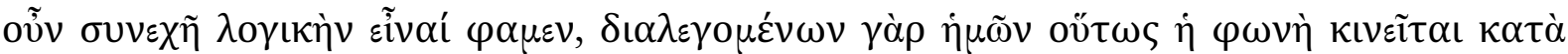

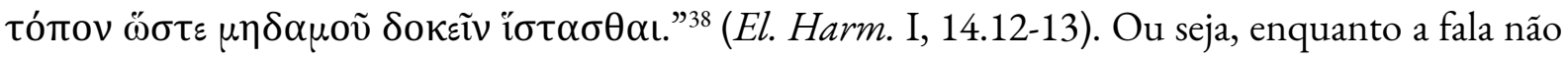
quer estacionar em uma região, o canto deseja permanecer em alturas determinadas, procurando a afinação, mediante tensão e relaxamento, sob uma organização rítmica.

Em suma, pode-se dizer que, quando não se realiza o movimento contínuo, mas o movimento por intervalos ${ }^{39}$, não se fala, mas canta-se. Lembrando, também, que a descrição de intervalos, para Aristóxeno, deve ser feita à luz da cognição sensível, ou seja, da percepção do ouvido ${ }^{40}$. A capacidade de afinação do cantor consiste em sua habilidade em manter a voz sempre nos mesmos pontos fixos, a partir da mecânica vocal entre tensão e relaxamento.

No entanto, ambas as categorias, canto e fala, não são necessariamente absolutas, podendo haver tendência à fala no canto ${ }^{41}$, e tendência ao canto na fala. A medida é a predominância de movimento, quer contínuo quer intervalar. Reitera-se que o canto deseja estacionar o quanto queira; já a fala, pelo contrário, evita permanecer em regiốes determinadas da voz. Quando ela tende a estacionar, sob oscilações não tão controladas, é porque o falante deseja expressar alguma emoção forte. Por inferência, o movimento intervalar é mais propício aos afetos ou mais passível de expressão e controle.

Em relação à afinação, que é o ponto estacionado já definido, Aristóxeno afirma que quanto mais idênticas são as mudanças entre os pontos estacionários, mais correto o canto soará ao ouvido. Evidentemente, quando se canta 'para cima' (tensão) ou 'para baixo' (relaxamento) ${ }^{42}$, evita-se proferir

38 Dizemos que a fala é contínua; nesse sentido, o som é colocado em movimento ao invés de permanecer estacionado em uma região.

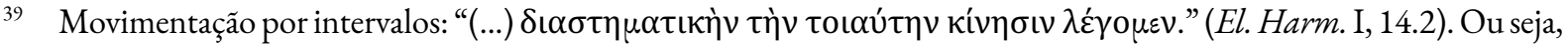
“(...) falamos sobre aquele movimento que se procede por intervalos".

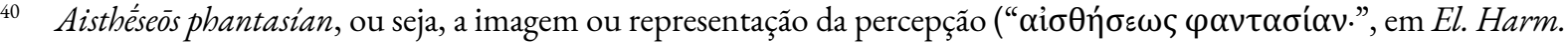
I, 13.22-23).

41 Os processos inventivos da composição possibilitam explorar muitos recursos vocais, tais qual incluir, no canto, aspectos expressivos da fala. Nesse sentido, esses recursos acústicos próprios da fala tornam-se dados formais na música. Por isso, recursos vocais como o Sprechgesang ("canto falado"), termo de Schönberg (1874-1951), pode ser entendido como efeito de fala no canto (KRÄMER, 1972). Ressalte-se que não é, a rigor, fala, mas ainda canto, suscitando efeito de fala, isto é, de continuidade e atonalismo.

42 Em Aristóxeno, a tensão, mais especificamente, é a transição contínua da voz da posição mais baixa à mais alta; já o relaxamento é a transição do mais alto ao mais baixo. Por conseguinte, a altura é o resultado da tensão; já a profundidade, do relaxamento. A afinação acontece quando o som torna-se estacionário e para de oscilar. Em outras palavras, a altura da afinação ocorre, de fato, quando não há mais tensão. Ou seja, a afinação é, em suma, a persistência ou a posição estacionária da voz. Logo, é importante diferenciar altura de afinação. 
as mudanças de tensionamento, senão revelar acusticamente somente os pontos estacionários. $\mathrm{O}$ cantor que profere as passagens de tensão e relaxamento e não mantém perfeita regularidade entre as mudanças tem a sua execução prejudicada, uma vez que ele se aproxima mais da fala do que do canto ou incomoda o ouvido.

Nesse sentido, questiona-se o desempenho vocal de cantores que, em shows da indústria da cultura, realizam, na verdade, função de fala, mediada parcialmente por intervalos de raro estabelecimento de altura, quanto menos de afinação. Ou seja, sob risco de anacronia - mas sob liberdade de imaginação - seria altamente improvável que Aristóxeno denominasse músico ou cantor aquele "cantor de microfone” (conferir expressão em: RICCIARDI, 2020), salvo raríssimas exceçôes. Esses shows costumam ser desprovidos de técnica de canto, sequer de afinação. Ou seja, é bem difícil que o grego de Tarento reconhecesse haver canto, por definição, nessas atividades de fala estendida de microfone, sob pretexto de execução musical.

Nesse viés, por “cantor de microfone”, entendemos o tipo de voz que se tornou padrão na indústria da cultura (Kulturindustrie), que depende da erudição tecnológica para amplificar a voz e corrigir a acústica (RICCIARDI, 2020, passim). Em muitos casos, tendo em vista a distinção entre canto e fala, observa-se a predominância de movimentos vocais assistemáticos, sem intervalos determinados na execução de falantes de microfone (questiona-se a presença sequer de algum elemento do sistema musical). Há, senão, somente o ato contínuo da voz, em oscilações ou alterações de pontos fixos sem percepção adequada - isso sem mencionar a qualidade do texto que se "canta".

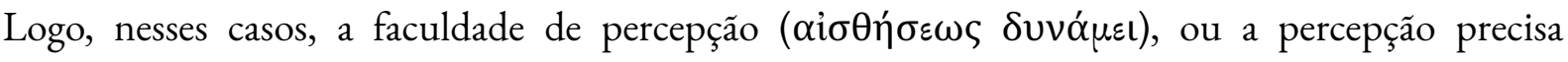

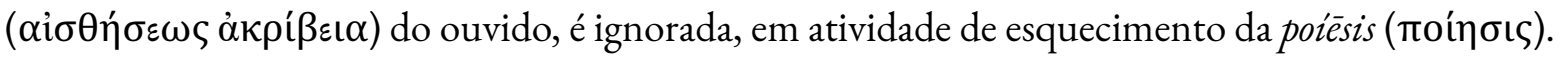

Aristóxeno, mesmo preocupado com a música sob o ponto de vista teórico-filosófico, percebeu a importância da percepção auditiva para a concepção e realização da música, em sua dimensão poética. Sob esse viés, o canto necessita de uma perfórmance - prâxis de uma poiêsis, crítica e inventiva - integrada ao sistema musical, a todos os seus elementos, tais quais altura, timbre, intensidade, duração etc. Se essa práxis não tem afinidade com a inventividade artística, ela é mera atuação sob pretexto musical. Mais uma vez, as categorias de canto e fala estão fadadas a se confundirem no pensamento que já se esqueceu da poíésis.

A falta de triagem epistemológica pode resultar em agravantes conceituais que afetam distintas 
áreas do conhecimento, como é o caso da confusão entre métrica de línguas antigas e partitura musical, tendo em vista uma possível confluência terminológica entre sistemas no estabelecimento da rítmica e da prolação musical. Por essa razão, Aristóxeno preocupou-se em organizar a epistemologia dentro de sua área de atuação, sem recusar-lhes as imbricações pluriepistêmicas. No entanto, sempre sob rigor da clareza conceitual, o músico diferiu, por exemplo, dança, poesia e música - artes que possuem conceitos comuns ou semelhantes, tais quais pés, ritmo, tempo, metro e prosódia, cujas especificidades são estabelecidas a partir da configuração dos elementos de um sistema.

Assim, o estudo crítico-reflexivo de um mesmo conceito que exista em distintas áreas, não somente artísticas e filosóficas, bem como de seu desdobramento metafórico, pode auxiliar na compreensão do fenômeno epistemológico, de como os conceitos migram de uma área para outra e ganham novas acepções ou mantêm-nas. Por isso, preocupado em distinguir sistemas entre línguas e entre linguagens, não se reconheceram, nos versos de Shakespeare, pentâmetros jâmbicos, senão decassílabos; mas se perceberam, mesmo que artificialmente, hexâmetros datílicos nos versos de Virgílio. Logo, cada língua tem o seu sistema métrico-prosódico determinado, mesmo que não o saibamos pronunciar. Também sob esse rigor semântico, procurou-se distinguir quantidade vocálica de duração rítmica, tendo a clareza de que vogais longas e breves não são semínimas e colcheias, para o estabelecimento quer da prosódia greco-latina, quer da musical.

Por fim, categorizaram-se, a partir de Aristóxeno, a fala e o canto mediante a moção da voz, quer a tendência ao movimento contínuo, característica da fala, quer a tendência a pontos fixos, em movimento intervalar, mais próprio do canto. Nesse ensejo, considera-se a diferença entre altura e afinação. Logo, a essência da distinção entre canto e fala é a natureza do movimento da voz. Ademais, justificou-se, sob esse raciocínio, a perfórmance do cantor, necessariamente a prâxis de uma poiesis, crítica e inventiva.

\section{AGRADECIMENTOS}

Fundação de Amparo à Pesquisa do Estado de São Paulo (FAPESP); Processo no 2018/01418-2. 


\section{REFERÊNCIAS}

ADORNO, Theodor W.; HORKHEIMER, Max. Dialektik der Aufklärung. Frankfurt: Fischer, 1969 [1944, 1ㄹ ed. 1947].

ANDRADE, Mário de. Pequena história da música. Rio de Janeiro: Nova Fronteira, 2015.

ARISTOTELES et al. [Euclides, Nicomachus, Bacchius, Gaudentius, Alypius]. Musici scriptores Graeci. Recognovit prooemis et indice instruxit Carolus Janus. Lipsiae: Teubner, 1895.

ARISTÓTELES. Retórica. Tradução de Manuel Alexandre Júnior, Paulo Farmhouse Alberto e Abel do Nascimento Pena. São Paulo: WMF Martins Fontes, 2012.

ARISTOXENOS von Tarent. Melik und Rhythmik des Classischen Hellenenthums. II Band.

Berichtigter Originaltext mit Prolegomena von R. Westphal. Herausgegeben von F. Saran. Leipzig: Ambr. Abel, 1883.

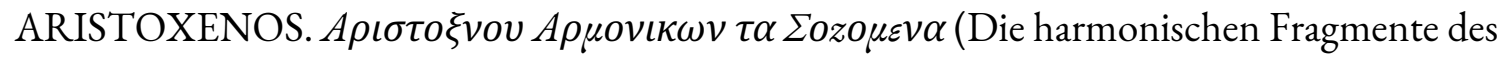
Aristoxenus). Herausgegeben von Paul Marquard. Berlin: Weidmannsche Buchhandlung, 1868.

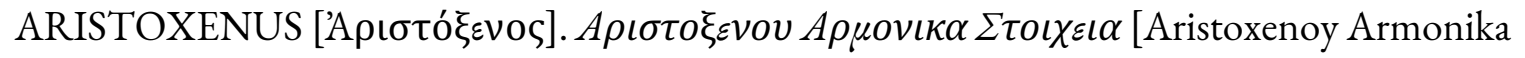
Stoikheia]. The Harmonics of Aristoxenus. Edited with translation notes, introduction and index of words by Henry S. Macran. Oxford: Clarendon Press, 1902.

ARISTOXENUS. Aristoxenus Elementa Rhythmica: the Fragments of Book II and the additional evidence for Aristoxenean rhythmic theory. Edited by Lionel Pearson. Oxford: Clarendon Press, 1990.

BAUMGARTEN, Alexander Gottlieb. Theoretische Ästhetik. [aus d. Aesthetica]. Hamburg: Meiner, 1983 [1750/58].

CÍCERON. Tusculanes. Traduit par Jules Humbert; texte établi par G. Fohlen. Tome I, Livres I-II. Paris: Les Belles Lettres, 1930.

GARLANDIA, Johannis de. De Musica mensurabili. In: COUSSEMAKER, E. de. Scriptorum de Musica Medii Aevi: novam seriem a gerbertina alteram. Tomus I. Parisiis: A. Durand [Typis Lefebvre-Ducrocq.], 1864. Disponível em:

https://books.google.com.br/books?id=e1dUFtPT1m4C\&printsec $=$ frontcover\&redir_esc $=y \# v=0$ nepage\&q\&f=false. Acesso em: 09 set. 2020.

GARLANDIA, Johannes de. De musica mensurabili positio. Transcribed by Sandra Pinegar et al. Paris: Bibliothèque nationale de France. [Online, Thesaurus Musicarum Latinarum]. Disponível em: http://www.chmtl.indiana.edu/tml/13th/GARDMP_MPBN1666. Acesso em: 12 out. 2020. GIBSON, Sophie. Aristoxenus of Tarentum and the Birth of Musicology. Edited by Dirk Obbink and Andrew Dyck. New York \& London: Routledge, 2005.

KRÄMER, Ulrich et al. Schönberg und der Sprechgesang. München: Richard Boorberg Verlag GmbH \& Co, 1972.

LIMA, Alceu Dias. Uma Estranha Lingua? Questões de linguagem e de método. São Paulo: Edunesp, 1995. 
LIMA, Alceu Dias; THAMOS, Márcio. Verso é para cantar: e agora, Virgílio? ALFA Revista de Linguística, São Paulo, n. 49 (2), 2005. Disponível em:

<https://periodicos.fclar.unesp.br/alfa/article/view/1407/1108>. Acesso em: 03 out. 2020.

ODINGTON, Walter [Walteri Odington]. Summa de speculatione musicae. Edited by Frederick F. Hammond, col. Corpus scriptorum de musica, vol. 14. Rome: American Institute of Musicology, 1970. Disponível em: http://www.chmtl.indiana.edu/tml/14th/ODISUM. Acesso em: 28 ago. 2020.

QUINTILIANUS, Aristides. De Musica [Peri Mousikes]. Libri III. Edidit Albertus Iahnius. Berolini: S. Calvaryus et sociis, 1882.

RAFFA, Massimo. Music in Greek and Roman Education [Cap. 22]. In: LYNCH, Tosca A. C.; ROCCONI, Eleonora (ed.). A companion to Ancient Greek and Roman Music. New Jersey: Wiley Blackwell, 2020., p. 311-322.

RICCIARDI, Rubens Russomanno. Cantor e Cantor de microfone: discussão conceitual sobre música, música popular e indústria da cultura. Revista da Tulba [S. 1.], Ribeirão Preto (SP), v. 6, n. 1, p. 110-139, 2020. Disponível em: http://www.revistas.usp.br/revistadatulha/article/view/170647/161834. Acesso em: 16 set. 2020. ROESNER, Edward H. (Org.). Ars Antiqua. Organum, Conductus, Motet. London and New York: Routledge, 2016.

SAUSSURE, Ferdinand de. Cours de Linguistique Générale. Publié par Charles Bally et Albert Sechehaye. Paris: Payot, 1969.

SHAKE-SPEARES. The Sonnets, Quarto 1 [Neuer before Imprinted. At London, By G. Eld for T. T and are to be solde by William Aspley]. London: Thomas Thorpe, 1609. Fac-símile disponível em: https://internetshakespeare.uvic.ca/Library/facsimile/overview/book/Q1_Son.html. Acesso em: 28 set. 2020.

STAATLICHE Antikensammlungen und Glyptothek. Vasen 2646 (Douris). Vasen aus Athen. München: Antikensammlungen [Online]. Disponível em :<https://www.antike-amkoenigsplatz.mwn.de/index.php/de/>. Acesso em: 12 out. 2020. [Imagem de vaso ateniense da galeria de fotos de ArchaiOptix: https://commons.wikimedia.org/wiki/User:ArchaiOptix].

THAMOS, Márcio. Do hexâmetro ao decassílabo - equivalência estilística baseada na materialidade da expressão. Scientia Traductionis, Florianópolis, EDUSFC, n. 10, 2011. Disponível em: https://repositorio.unesp.br/handle/11449/124866. Acesso em: 25 ago. 2020.

VIRGILE. Énéide. Trad. André Bellessort. Paris: Les Belles Lettres, 1952.

\section{SOBRE OS AUTORES}

Paulo Eduardo de Barros Veiga é pós-doutorando pela Faculdade de Filosofia, Ciências e Letras de Ribeirão Preto, Departamento de música, sob supervisão do Prof. Dr. Rubens Russomanno Ricciardi. Recebe apoio da Fundação de Amparo à Pesquisa do Estado de São Paulo (FAPESP), sob processo de número 2018/01418-2. É membro do Núcleo de 
VEIGA, Paulo Eduardo de Barros; RICCIARDI, Rubens Russomanno. Distinções primordiais entre Canto e Fala a partir de Aristóxeno de Tarento. Revista Vórtex, Curitiba, v.9, n.1, p. 1-28, 2021.

Pesquisa em Ciências da Performance em Música (NAP-CIPEM) e do Grupo Linceu - Visões da Antiguidade Clássica. Além de violinista da USP Filarmônica e da Oficina Experimental, tem Mestrado e Doutorado em Estudos Literários, voltando-se à literatura clássica, pela Universidade Estadual Paulista, Faculdade de Ciências e Letras de Araraquara. ORCID: https://orcid.org/0000-0002-1250-8237. E-mail: pauloveiga@usp.br

Rubens Russomanno Ricciardi é professor titular do Departamento de Música da FFCLRP-USP, compositor, maestro, pianista e musicólogo. Graduado pela ECA-USP, com especialização em Musicologia pela Universidade Humboldt de Berlim, sua carreira contempla Mestrado, Doutorado e Livre-docência, além de concurso para Professor titular, pela ECAUSP. É fundador do Curso de Música da FFCLRP-USP, do Ensemble Mentemanuque, da USP Filarmônica e do NAPCIPEM. Também é professor responsável pelo Festival Música Nova “Gilberto Mendes”, pelo Projeto USP Música-Criança e pelas séries Concertos USP/São Carlos e Concertos USP/Theatro Pedro II. Suas composições têm sido apresentadas em centros musicais no Brasil, na América do Norte e na Europa. ORCID: https://orcid.org/0000-0002-6895-2177. E-mail: rubensricciardi@gmail.com 